\title{
Increase in oil content and changes in quality of macauba mesocarp oil along storage
}

\author{
Wogayehu Worku Tilahun ${ }^{1, *}$, José Antonio Saraiva Grossi ${ }^{1}$, Simone Palma Favaro ${ }^{2}$, Carlos Sigueyuki \\ Sediyama $^{1}$, Samuel De Melo Goulart ${ }^{1}$, Leonardo Durate Pimentel ${ }^{1}$ and Sergio Yoshimitsu Motoike ${ }^{1}$ \\ ${ }^{1}$ Universidade Federal de Viçosa, Departamento de Fitotecnia, Viçosa, MG, Brazil \\ 2 Embrapa Agroenergia, Brasília, DF, Brazil
}

Received 5 February 2019 - Accepted 19 March 2019

\begin{abstract}
Macauba is an oleaginous palm species from Latin America. It is a rich source of vegetable oil with diverse benefits. However, there are several gaps in assuring post-harvest oil quality of the mesocarp. Thus, ripe fruits were stored at room temperature for 60 days before oil extraction to evaluate fruit and mesocarp oil quality attributes. Physical (decay incidence, water activity), biochemical (specific activity of lipase), physicochemical (acidity and peroxide indices, molar absorptivity at $\mathrm{K}_{232}$ and $\mathrm{K}_{270}$, oxidative stability, total carotene content and mesocarp colour) analyses were carried out. Results show that nonlinear sigmoid response was obtained for most of the parameters evaluated. Decaying reactions related to microorganism's growth, free fatty acid release and oxidation took place along storage. However, the overall oil quality was in the acceptable limits up to 20 days of storage. It is much further than palm oil, the main source of oil in the world.
\end{abstract}

Keywords: Acrocomia aculeata / post-harvest / oil quality / free fatty acid / oxidation

Résumé - Augmentation de la teneur en huile et modification de la qualité de l'huile issue du mésocarpe de macauba au long du stockage. Le macauba est une espèce de palmier oléagineux d'Amérique latine. C'est une riche source d'huile végétale aux avantages divers. Cependant, plusieurs facteurs peuvent altérer la qualité du mésocarpe après la récolte. Ainsi, des fruits mûrs ont été conservés à température ambiante jusqu'à 60 jours avant l'extraction de l'huile afin d'évaluer les paramètres qualitatifs des fruits et de l'huile du mésocarpe. Des analyses physiques (incidence de la décomposition, activité de l'eau), biochimiques (activité spécifique de la lipase), physicochimiques (indices d'acidité et de peroxyde, absorption molaire à K232 et K270, stabilité à l'oxydation, teneur en carotène total et couleur du mésocarpe) ont été effectuées. Les résultats montrent qu'une réponse sigmoïde non linéaire a été obtenue pour la plupart des paramètres évalués. Des réactions de décomposition liées à la croissance de microorganismes, à la libération d'acides gras libres et à l'oxydation ont eu lieu tout au long du stockage. Cependant, la qualité globale de l'huile demeurait dans des limites acceptables jusqu'à 20 jours de stockage. C'est beaucoup plus que l'huile de palme, la principale source d'huile dans le monde.

Mots clés : Acrocomia aculeata / après récolte / qualité de l'huile / acide gras libre / oxydation

\section{Introduction}

Macauba [Acrocomia aculeata (Jacq.) Lodd.ex. Mart] is a single stemmed spiny palm widely distributed in tropical and subtropical America. It can be used for human food, medicine,

\footnotetext{
*Correspondence: wogayehuworku53@gmail .com; wogayehuworkut@yahoo.com; henokwgh7@gmail.com
}

animal feed, fiber, biodiesel and cosmetics industry (Lorenzi and Negrelle, 2006; Poetsch et al., 2012). Pires et al. (2013) reported that the economic feasibility of this palm tree relays on its high oil productivity and whole usage of the fruit to generate products and co products upon processing. Beyond the high biomass yield, macauba has shown its potential to cultivation because of its favourable energy-balance and greenhouses gas emissions (Evaristo et al., 2018). Macauba fruit can render directly oil with high oleic acid and carotene 
content and rich fiber cake from mesocarp; high lauric oil and rich protein cake from kernel; biomass from husk, and hardy endocarp to be taken as solid fuel (Evaristo et al., 2016a). Moreover, other high benefit bioproducts could be developed from macauba compounds depending on the overall fruit quality. Mesocarp (pulp) portion provides the majority of the macauba fruit oil and it is featured by high water content that challenges to store and process the fruits. Macauba fresh fruit presents itself high quality mesocarp oil, even when it is dried immediately after harvesting, if good practices of harvest and processing are applied (Nunes et al., 2015).

Nevertheless, deployment of quality can be expected during storage depending on the conditions, due to hydrolytic and oxidative reactions upon lipids. The oil acidification may be caused by endogenous and microbial lipase that boosts hydrolysis of triacylglycerol delivering free fatty acids and other related compounds into oil. Acidity is one of the vital quality indices in fats and oil processing and marketing, and the deacidification process has economic implications on the value chain (Bhosle and Subramanian, 2005; Mariano et al., 2011).

In tropical humid countries, the impact of storage time on the quality of agricultural product might be pronounced. The current practice of macauba fruits exploitation, based on recollection of wild dropped fruits, and extraction of oil by pressing from naturally dried fruits without reasonable storage conditions, has rendered unsuitable mesocarp oil either for food or biofuel purposes. To overcome this scenario and bring macauba to the agribusiness there is a need to develop full technological packages to settle processing pathways.

Some attempts using distinct strategies to extend the shelf life of macauba fruits without compromising the mesocarp oil quality have been reported (Cavalcanti-Oliveira et al., 2015; Evaristo et al., 2016b). However, basic knowledge about the factors encompassed in the oil changes in the post-harvest remains mostly unknown. An important asset of the macula fruit is the further oil biosynthesis that takes place after abscission. Evaristo et al. (2016b) reported an increase of 35\% in oil content of the macauba mesocarp after 40 days of storage under room conditions. The acidity index could be kept under the acceptable limit during some time along the storage depending on the applied process conditions. This unique characteristic of macauba distinguishes it from the main and current vegetable oil source that is oil palm (Elaeis guineensis). Oil palm processing must take place no more than $48 \mathrm{~h}$ after bunches recollection in order to prevent the acidification to prohibitive levels (Shahidi, 2005), besides there is no oil gain in the post-harvest. The matching of low acidity and higher oil yield could boost the macauba exploitation in tropical and subtropical regions, including drier areas like Cerrados and Semiarid biomes in Americas. Besides the release of the free fatty acids, the oil quality can be compromised by oxidation reactions which result in undesirable sensorial and technological products (Chaiyasit et al., 2007).

This work aims to provide knowledge about post-harvest behavior of macauba fruits that can be useful to build up a successful macauba processing. The findings of this study could predict the storage potential of macauba fruit under room temperature with optimum oil quality for further use. Therefore, the objective of this work was to assess the mesocarp oil content and quality, and biochemical aspects of fresh macauba fruits stored at room conditions with increasing storage times.

\section{Material and methods}

\subsection{Experimental material}

Fruits were collected at full maturity from bunches that were cut from randomly selected wild macauba trees in Capela farm, Acaiaca municipality, Minas Gerais State, Brazil. Harvesting was done by hand using sickle fitted on long metal rods. Harvested fruits were sorted to have uniform size. Each experimental unit consisted of 20 fruits contained in polyethylene mesh bag.

\subsection{Storage treatments}

Each experimental unit was replicated five times and randomly placed in open plastic box, and was stored for $0,3,6$, $9,12,15,20,25,30,45,60$ days under room temperature $\left(23 \pm 1{ }^{\circ} \mathrm{C}\right)$ at Macauba Biotechnology and Post-harvest Laboratory, Universidade Federal de Viçosa. The fruits were manually pulped and the mesocarp was prepared for respective analyses. Biochemical analysis was subjected to ten analytical replicates; whereas oil quality parameters were subjected to three analytical determinations. Each data point in the graph indicates mean \pm standard error of five replications. All chemicals used were of analytical grade.

\subsection{Physical analysis of mesocarp}

Decay incidence (DI,\%) was evaluated considering the number of fruits that showed decay symptom on the outer part of the peeled mesocarp per total number of fruits in each replication, where 1 was scored for symptom presence and 0 for absence.

Manually peeled and pulped macauba fruit mesocarp slices were cut into small pieces, half filled in sample cup to measure water activity $\left(\mathrm{Ma}_{\mathrm{w}}\right)$ using Aqua Lab 4TE water activity meter (Decagon, Inc., USA) at an accuracy of $\pm 0.003 \mathrm{a}_{\mathrm{w}}$ at $25^{\circ} \mathrm{C}$.

Recently peeled fruits had the opposite sides slightly cut to measure the mesocarp colour by using colourimeter (CR-10, Konica Minolta Sensing, Inc.). The result was interpreted as per Hunter color Lab 2001 scale into the corresponding colour value. Accordingly, $\mathrm{L}$ is lightness $(+\mathrm{L}=$ light and $-\mathrm{L}=$ dark) ranging from 0 (white) to 100 (black), $\mathrm{A}$ is the red/green axis $(+\mathrm{a}=\mathrm{red},-\mathrm{a}=$ green and 0 is neutral), and $\mathrm{B}$ is the blue/ yellow axis $(+b=$ yellow, $-b=$ blue and 0 is neutral $)$.

\subsection{Biochemical analysis of mesocarp}

The specific activity of lipase (SAL) from the macauba mesocarp fruit was evaluated. To get the crude enzyme extract, an aliquot of $1 \mathrm{~g}$ mesocarp was homogenized with $20 \mathrm{~mL}$ of $0.1 \mathrm{M}$ Tris buffer at $\mathrm{pH} 8.0$ using blender. The homogenate was filtered through double layer cotton gauze and centrifuged at $6000 \mathrm{rpm}$ (Excelsa ${ }^{\mathrm{TM}}$ II Centrifuge, Mod.206 BL, Brazil) for 10 minutes. The supernatant was collected and stored at $-20^{\circ} \mathrm{C}$ (Iaderoza and Baldini, 1991). Protocols for lipase activity and soluble protein content were after Iaderoza and Baldini (1991) with modifications.

Lipase activity (unit/mole) was measured using a mixture of $1 \mathrm{~mL}$ of crude enzyme extract, $5 \mathrm{~mL}$ of triacetin emulsion 
a)

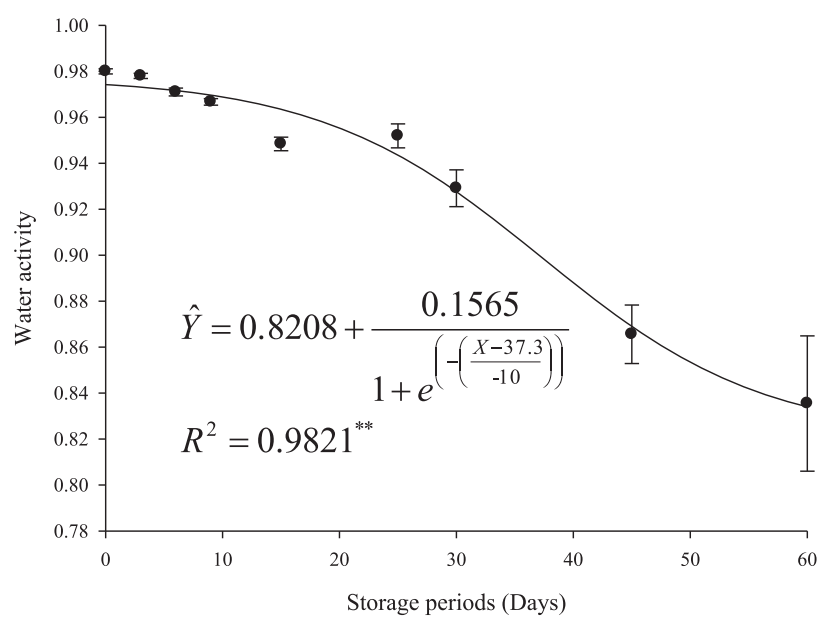

b)

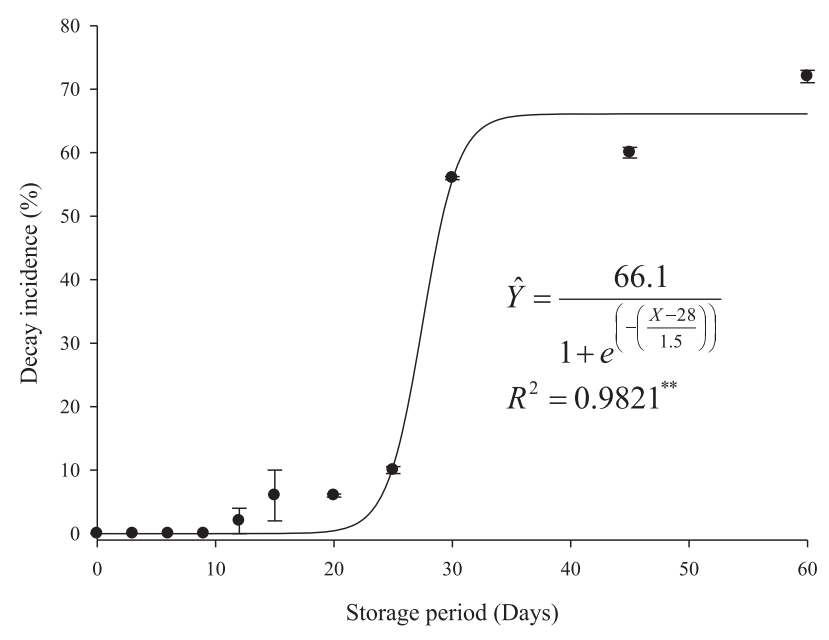

Fig. 1. Physical analyses of macauba fruit. a: mesocarp water activity $\left(\mathrm{Ma}_{\mathrm{w}}\right)$; b: decay incidence (DI, \%) along different storage periods. Error bars represent standard errors of the mean.

(25\% triacetin $/ 75 \%$ of $7 \%$ gum Arabic solution) and $5 \mathrm{~mL}$ of $0.1 \mathrm{M}$ TrisHCl buffer at $\mathrm{pH} 8.0$, incubated in water bath at $27^{\circ} \mathrm{C} / 30 \mathrm{~min}$. The reaction was stopped by adding $20 \mathrm{~mL}$ acetone: ethanol solution $(1: 1)$. The mixture, added with 5 drops of $0.05 \%$ phenolphthalein was titrated against $0.05 \mathrm{~N}$ $\mathrm{NaOH}$. The soluble protein content of the crude enzyme extract was measured by spectrophotometer at 260 and $280 \mathrm{~nm}$. The soluble protein content was used to calculate specific activity (U/mg) of the enzyme.

\subsection{Physicochemical analysis of mesocarp oil}

Mesocarp slices were dried in an oven with renewal and circulation of air (Tecnal, Model TE 394-3, Brazil) at $65^{\circ} \mathrm{C}$ for 12 hours. Then, the oil was extracted using a manually operated hydraulic press (Prensa Ribeiro 30 Ton, Brazil). The extracted oil was stored at $-20^{\circ} \mathrm{C}$ packed in amber glass vials wrapped with aluminum foil for further analysis.

Acidity and peroxide indices were determined as per AOCS (1983). Acidity was expressed as free fatty acid (oleic acid \%). Peroxide index was given as milli equivalents of active oxygen per kilogram of oil (meq $\mathrm{O}_{2} / \mathrm{kg}$ ).

Primary and secondary degree of oil oxidation was determined by molar absorptivity at $232 \mathrm{~nm}\left(\mathrm{~K}_{232}\right)$ and $270 \mathrm{~nm}\left(\mathrm{~K}_{270}\right)$, respectively, according to AOCS (2004) by diluting the oil sample in $10 \mathrm{~mL}$ isooctane.

The oxidative stability was measured by Rancimat method (873 Biodiesel Rancimat_Metrohm) as per AOCS (1997), and expressed as the induction time (hours) measured at $110^{\circ} \mathrm{C}$ and air flow of $10 \mathrm{~L} / \mathrm{h}$.

Total carotene content was determined by diluting the oil samples in $10 \mathrm{~mL}$ petroleum ether and taking the absorbance at $450 \mathrm{~nm}$ (Rodriguez-Amaya and Kimura, 2004).

\subsection{Experimental design and data analysis}

The experiment was arranged in a completely randomized design with five replications per treatment. Regression analysis was carried out considering storage time as independent variable using Sigma Plot 10 statistical software (Sigma Plot 10, 2006).

\section{Results and discussion}

\subsection{Physical analysis of mesocarp}

Water activity is a measure of unbound water in a biological system and is strongly related to microbial growth and chemical and enzymatic reactions (Maltini et al., 2003). Mesocarp water activity $\left(\mathrm{Ma}_{\mathrm{w}}\right)$ was significantly $(P<0.0001)$ different along periods of storage following a nonlinear sigmoid trend with $\mathrm{R}^{2}$ of $98.2 \%$ (Fig. 1a). It was decreased from $0.9742 \pm 0.0011$ at 0 day to $0.8341 \pm 0.0294$ at the 60 th day. Sharp decline of $\mathrm{Ma}_{\mathrm{w}}$ was observed after 37 days. The nature of macauba mesocarp is mucilaginous and fibrous (Lorenzi and Negrelle, 2006), with sticky property. Its tasty and attractive flavour at maturity is partially due to the nonreducing sugars (Montoya et al., 2016). In such kind of matrix the water is linked to the solutes that prevent its release and, consequently, slow decrease in $\mathrm{a}_{\mathrm{w}}$. This water linkage and the barrier to its exit, provided by the husk, avoided a deeper reduction of $\mathrm{Ma}_{\mathrm{w}}$. At the 60th day of storage, $\mathrm{Ma}_{\mathrm{w}}$ was reduced only by $14.4 \%\left(0.8341 \mathrm{a}_{\mathrm{w}}\right)$. This value indicated that there were favourable conditions for microbial growth to take place, mainly fungus and yeasts that could be related to fruit decay and oil quality degradation.

The integrity of the exocarp appears as a barrier for microorganisms to penetrate the mesocarp and initiate decaying process. In this work, bunches were carefully recollected by cutting them and dropping inside a collector with spongy surface underneath. This practice prevented the exocarp from mechanical damage and microbial contamination. Nevertheless, the exocarp of macauba fruit is porous and can permit entrance of microorganisms. Periods of storage were highly significant $(P<0.0001)$ on decay incidence (DI), following a sigmoid trend with $\mathrm{R}^{2}$ of $98.2 \%$ (Fig. 1b). Fruits had no decay symptoms up to 9 days of storage. From the 12th 


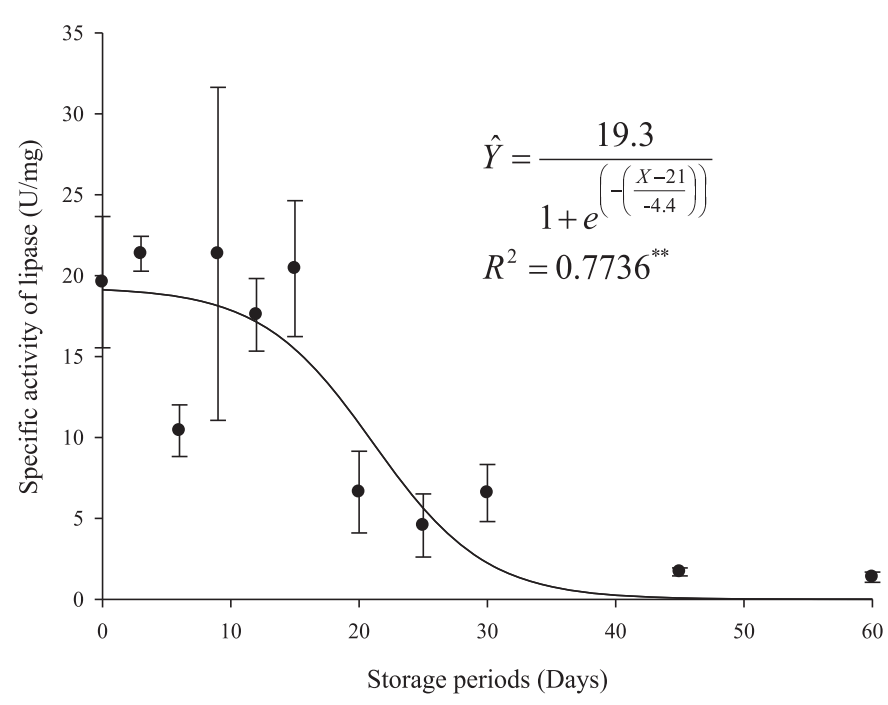

Fig. 2. Specific activity of lipase (SAL) of macauba mesocarp along different storage periods. Error bars represent standard errors of the mean.

to 25 th day, DI was observed in less than $10 \%$ of the fruits. However, within the 25 th and the 35 th day, $66 \pm 0.3 \%$ of the fruits were affected by some degree of DI. Afterwards, this rate did not change quite a lot for the remaining period of storage. No new spot of decay incidence does not mean that microbial growth ceased, as the measurement of the area under disease infection was not considered in this work.

The microbiota associated to the macauba mesocarp encompassed $45.2 \%$ yeast, $32.6 \%$ bacteria, and $22.2 \%$ fungi, according to an evaluation reported by Evaristo et al. (2016a). Bacteria are the most demanding in available water, they require water activity higher than 0.92 for their growth, followed by fungi whose growth and metabolism of secondary compounds occur at the limit of 0.7 . Yeasts are more resistant and can grow until 0.62 . Water activity observed in this study was high enough to allow the growth of all micro biota within the 30 initial days. Afterwards, water activity reduction restrained bacteria growth. Although water activity was in the suitable range for both fungi and yeasts growth all along the studied period, other factors could have prevented new spots of decay incidence developing in the macauba mesocarp in the last month of evaluation. So that further studies should be carried out to investigate thoroughly the relation between $a_{w}$ and microbial growth in macauba fruits in order to settle a safe range for the storage.

\subsection{Biochemical analysis of mesocarp}

Lipase cleaves the triglyceride molecule releasing free fatty acids causing the acidity of the oil to increase. In this study, lipase activity showed a specific activity of lipase (SAL) changing significantly $(P<0.003)$ along the length of storage following a sigmoid trend with $\mathrm{R}^{2}$ of $77.4 \%$ (Fig. 2). SAL was around $20 \mathrm{U} / \mathrm{mg}$ up to the 15 th day of storage. Afterwards, it showed a deep decrease within the next 10 days. After 45 days, SAL was near zero. SAL behavior seems to be associated with the available water. During the first two weeks, when lipase

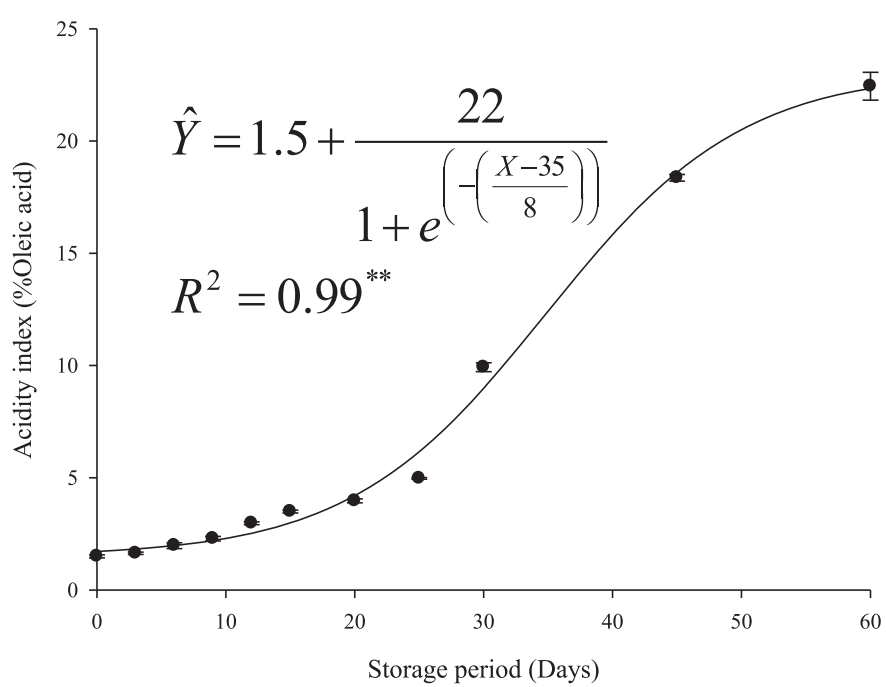

Fig. 3. Acidity index of the macauba mesocarp oil along storage under room conditions. Error bars represent standard errors of the mean.

was more active, $\mathrm{Ma}_{\mathrm{w}}$ showed values higher than 0.94 , and it decreased afterwards.

The whole fruits were not sanitized before being peeled to the removal of the mesocarp. Therefore, the protocol to measure the lipase activity employed in this study could encompasses both endogenous and microbial enzymes that comes from the growing flora associated with the inner mesocarp or the outer part of the husks.

\subsection{Physicochemical analysis of mesocarp oil}

Storage periods affected most of the quality parameters of the macauba mesocarp oil. Hydrolytic and oxidative reactions were more intense after the 20th day in macauba fruits that coincides with increasing pattern of DI (Fig. 1b).

Acidity index (free fatty acids in $\%$ oleic acid) was significantly $(P<0.0001)$ different for periods of storage following a sigmoid trend with $\mathrm{R}^{2}$ of $99.4 \%$ (Fig. 3). It was increased from $1.72 \pm 0.06 \%$ from freshly harvested fruits to $22.3 \pm 0.62 \%$ at the 60 th day. The pattern of TAG hydrolysis reaction in macauba mesocarp oil showed a small rise of slope up to the 20th day, and then it becomes much larger. The free fatty acid concentration was below the reference of the crude palm oil standard limit of 5\% at maximum as per Brazilian Health Surveillance Agency (ANVISA) (Brasil, 2005) until 22 days of storage.

The free fatty acid content of the raw material is an important trait whether in biodiesel production or food industries. The FFA content targeted by industries should be up to $3 \%$ for industrial application (Nunes et al., 2015). This was equivalent to 13 days of storage according to the adjusted regression model. Low acidity is required due to the sensorial attributes of vegetable oils, costs of the refining and conversion processes. For instance, biodiesel production is based on alkali transesterification that requires no more than 5\% FFA. Higher acidity demands acid based catalysis which is more expensive than the usual alkali one (Gerpen and Knothe, 2005). 
a)

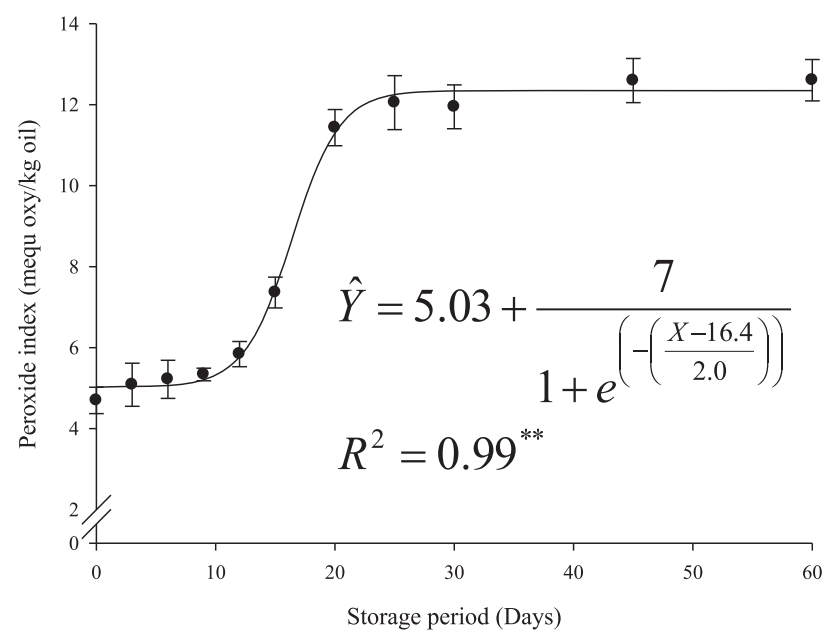

b)

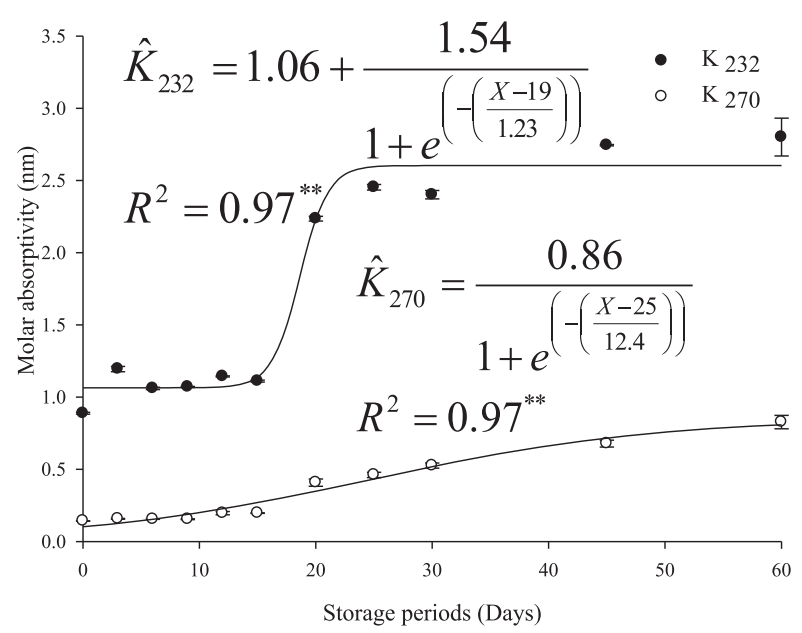

c)

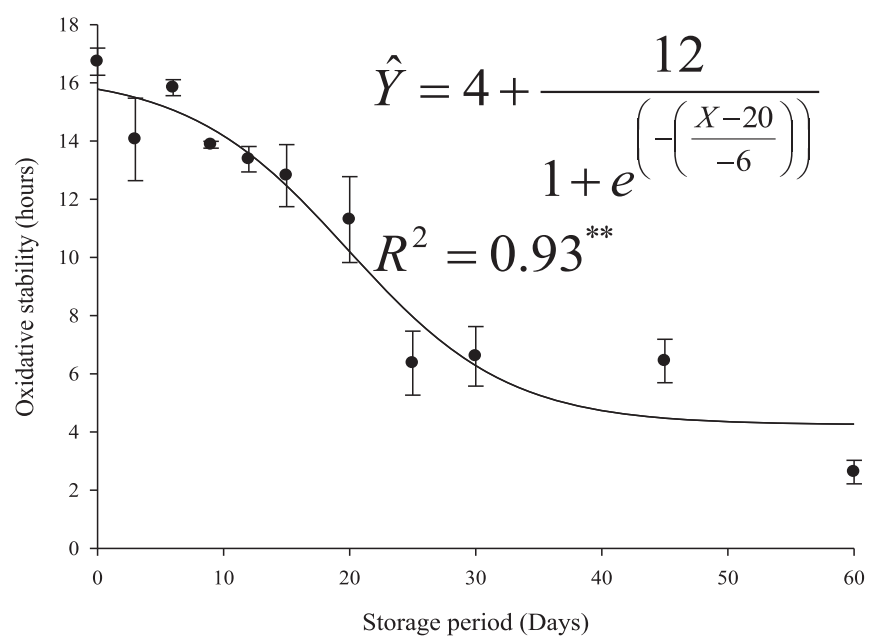

Fig. 4. Quality parameters of macauba mesocarp oil along fruit storage under room conditions. a: peroxide index (PI); b: molar absorptivities $\left(\mathrm{K}_{232}\right.$ and $\left.\mathrm{K}_{270}\right)$; c: oxidative stability index (OSI). Error bars represent standard errors of the mean.

The rise in acidity after 35 days seems not be related to lipase activity as it showed no more activity afterwards. Autocatalytic hydrolysis probably took place and kept releasing fatty acids from the TAG. Despite the increasing acidity observed in the mesocarp oil along the storage, macauba presented an important trait regard to this quality aspect compared to oil palm. AI in the former palm fruit develops much faster. After 7 days of storage, acidity in palm oil reached contents higher than $20 \%$ of free fatty acid (\% palmitic acid) and ended up with around $40 \%$ in the 40th day (Basyuni et al., 2017).

Another important quality aspect to the vegetable oils is the oxidative decay. There are several methods to evaluate it (Shahidi and Wanasundara, 2002). In this work three different protocols were employed: peroxide index (PI), molar absorptivities $\left(\mathrm{K}_{232}\right.$ and $\left.\mathrm{K}_{270}\right)$ and oxidative stability index (OSI). Lipids oxidation is characterized by the formation of peroxides and hydro peroxides as a primary stage of breakage at the double bonds of polyunsaturated fatty acids and can be detected by PI evaluation. The peroxide formation is a typical chain reaction that encompasses a small rate at the beginning and it will reach an exponential phase later on. In this study, the PI of the mesocarp oil showed significant $(P<0.0001)$ difference along storage periods of the fruits, following a nonlinear sigmoid trend with $\mathrm{R}^{2}$ of $98.6 \%$ (Fig. 4a). It was increased from $5 \pm 0.33$ at 0 day to $12.4 \pm 0.51 \mathrm{meq} \mathrm{O}_{2} / \mathrm{kg}$ oil at the 60th day. Initial PI up to18 days ranged within the standard of $10 \mathrm{meq} \mathrm{O}_{2} / \mathrm{kg}$ oil settled for crude palm oil as per Brazilian Health Surveillance Agency (ANVISA) (Brasil, 2005). After 20 days storage length the PI kept unchanged for the remaining time of storage. The steady amount of peroxides after 20 days does not imply necessarily cessation of lipids degradation. There could be formation of new peroxides at the same rate of their degradation into secondary compounds of oxidation.

Molar absorptivities $\left(\mathrm{K}_{232}\right.$ and $\left.\mathrm{K}_{270}\right)$ are the measure of primary lipid oxidation compounds, conjugated dienes and trienes, respectively (Shahidi and Wanasundara, 2002). Both 


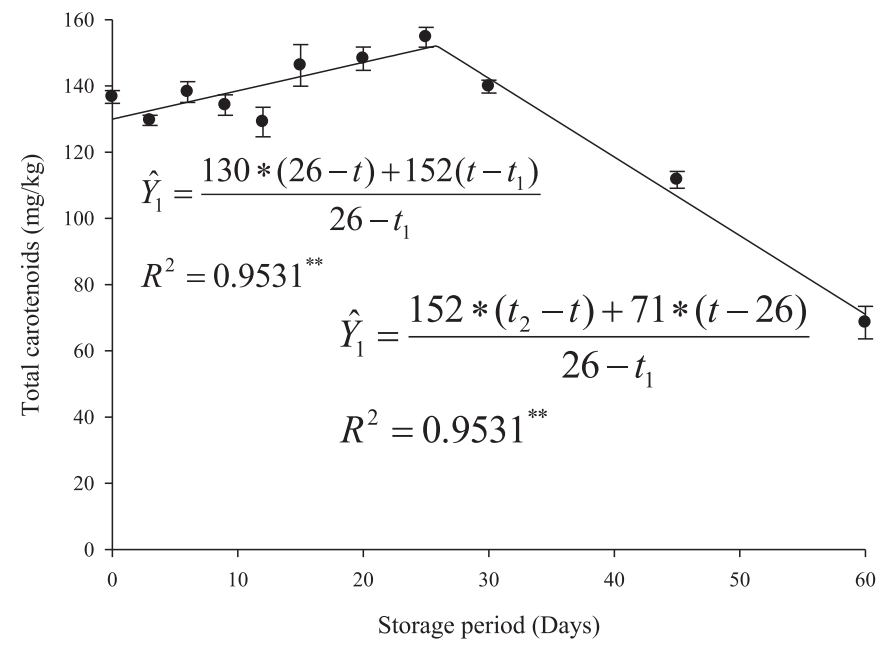

Fig. 5. Total carotenoids content (TC, $\mathrm{mg} / \mathrm{kg}$ ) of macauba mesocarp oil along storage. Each data point in the graph indicates mean $\pm \mathrm{SE}$ of 5 replications.

values increased along the storage length, and, therefore demonstrated that oxidation reactions took place. $\mathrm{K}_{232}$ increased from $1.07 \pm 0.01$ of the freshly harvested fruits to $2.60 \pm 0.13$ at the 60 th day $\left(\mathrm{R}^{2}=97.1 \%\right)$. The development of $\mathrm{K}_{232}$ was similar to the peroxide index. At $\mathrm{K}_{270}$ there was an increase from $0.10 \pm 0.002$ to $0.81 \pm 0.046$ at the 60 th day $\left(\mathrm{R}^{2}=97.3 \%\right)$ as shown in Figure 4. Currently there is little information about these parameters to macauba mesocarp oil. The first report of molar absorptivities of the crude mesocarp oil of macauba was within the range shown in this work, 2.04 at $\mathrm{K}_{232}$ and 0.56 at $\mathrm{K}_{270}$ (Nunes et al., 2015).

Oxidative stability index (OSI) is the resistance of oil to oxidation measured in an accelerated oxidation condition. The volatile products released during the oxidation are measured by the change in conductivity and the inflexion time is taken in hours to express OSI. OSI also contributes to determine the oil quality and shelf life, besides addressing uses to the vegetable oil sources.

In this study, OSI was significantly $(P<0.0002)$ different along periods of storage following a nonlinear sigmoid trend with $\mathrm{R}^{2}$ of $93.3 \%$ (Fig. $4 \mathrm{c}$ ). It decreased from $16 \pm 0.5 \mathrm{~h}$ at 0 day to $4.3 \pm 0.4 \mathrm{~h}$ at the 60th day. Evaristo et al. (2016a) showed that OSI also decreases in the mesocarp of macauba oil along the storage and, even fungicide treatment of the fruits did not prevail against losing oxidative stability. These authors mentioned an initial OSI to macauba mesocarp oil around $12 \mathrm{~h}$, shorter time than observed in this work.

Macauba mesocarp oil presented high OSI at $110^{\circ} \mathrm{C}$ compared to refined, bleached, and deodorized (RBD) vegetable oils as in soybean $(5.24 \mathrm{~h})$ and canola $(7.14 \mathrm{~h})$ (Anwar et al., 2003). Compared to palm oil (19.95 h) (Anwar et al., 2003), macauba's one was closer.

Propensity to oxidation of the fatty acid relays mostly on the number of unsaturations in the carbon chain. Kerrihard et al. (2015) demonstrated a rate of 1:3:12 (monounsaturated (MUFA): diunsaturated and triunsaturated fatty acids) in the leaning to the oxidation of a given fatty acid. Mesocarp macauba oil has high contents of MUFA and palmitic acid, which is a saturated fatty acid, 55-60\%, and $22-23 \%$, respectively (Nunes et al., 2015; Del Rio et al., 2016). Such fatty acid composition is similar to palm oil and differs to those of soybean and canola that are richer in polyunsaturated fatty acid (Kerrihard et al., 2015). Therefore, the desirable OSI shown by macauba mesocarp oil is mostly due to its fatty acid profile.

OSI is an important parameter to select fat and oils to biodiesel production. It is required OSI of 6 hours at the minimum for oily raw material to biodiesel. OSI of macauba mesocarp oil was kept to this limit for 31 days of length storage of the fruits. It is an important characteristic to be taken into account to apply macauba oil in the blends to biodiesel, mostly those ones based on soybean oil.

Macauba mesocarp oil is featured by its reddish colour, which is impaired by carotenes compounds (Coimbra and Jorge, 2011; Ramos et al., 2007). Carotenoids play an important role as antioxidant compounds. They can inactivate the singlet oxygen that induces the oxidation decay. In this study, Total carotene (TC) content was measured in the mesocarp macauba oil obtained from the stored fruits. There were significant $(P<0.001)$ differences along periods of storage following a piecewise bi-segmented linear regression line with $\mathrm{R}^{2}$ of $95.3 \%$ (Fig. 5). It ranged from $130 \pm 1.9$ in 0 day to $152 \pm 2.9$ at the 26 th day in region $1(17 \%$ increase $)$ and then declined drastically to $71.03 \pm 4.9 \mathrm{mg} / \mathrm{kg}$ at the 60th day in region 2 , which is a $53 \%$ decrease. The synthesis of carotenoids usually takes place with the ripening process and for macauba it seems it did not cease immediately after the abscission. Probably the fruit had conditions enough, like water availability and energy sources to carry on with carotenes production during some time after harvesting. The sharp decline after 26 days might be related to oxidation reaction revealed by increasing $\mathrm{PI}$ and $\mathrm{K}_{232}$ and $\mathrm{K}_{270}$. The decreasing of oxidative stability could also be associated to the carotenoids degradation.

Colour of mature fruits is related to the natural colourants and it changes with their break down that can turn into dark degraded compounds as the oxidized products from lipids. The colour of macauba mesocarp is due to carotenoids. Carotenes are highly unsaturated molecules and are susceptible to degradation by oxidation under storage conditions. Once degraded carotenes have no longer the preserved chromophore structure, than brilliant colours fade.

The intense yellowish colour seen in the fresh mesocarp is due to the values of $\mathrm{L}=75.2 \pm 0.7$ and $\mathrm{B}=53.8 \pm 1.2$ from Hunter colour Lab scale (2001) (Fig. 6). Along the storage, the colour change of the mesocarp relied mostly on the reduction of the yellow intensity (B), followed by the reduction of Lightness (L). The red colour intensity (A) was remained steady along all the evaluated periods. A sharp decline for B value was observed after 33 storage days that is in parallel to carotene content decreasing. At the 60th day, $\mathrm{L}=50.9 \pm 1.9$ and $\mathrm{B}=21.8 \pm 2.7$, still confers a yellowish colour, but less intense and bright.

\section{Conclusion}

Macauba fruit is one of the palm species endowed with high oil content in the mesocarp. As a climacteric fruit, it accumulates more oil in storage with low oil quality degradation as compared to oil palm. Though it is a 


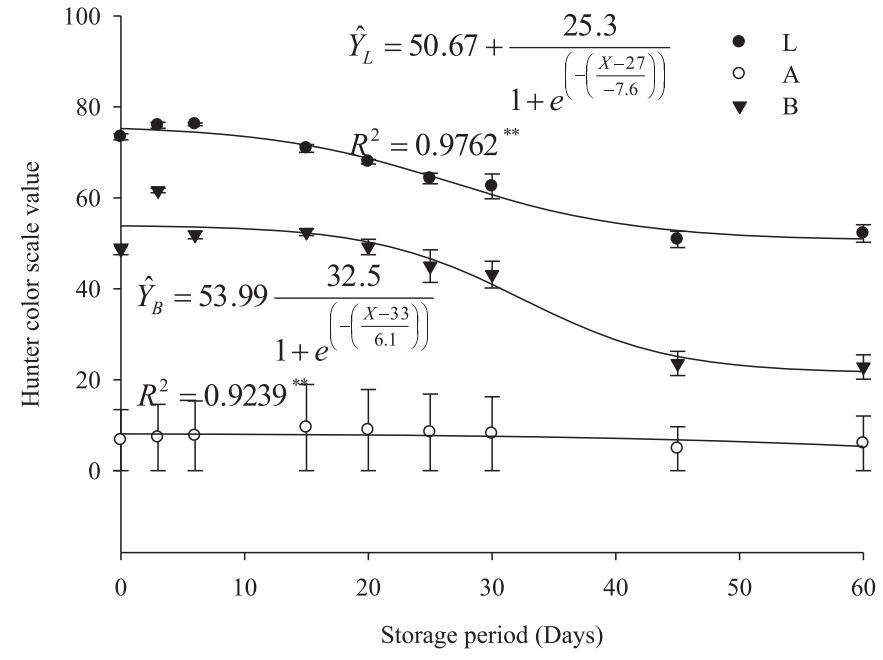

Fig. 6. Mesocarp color (MC) of stored macauba fruits. L: lightness; A: red/green axis; B: blue/yellow axis. Each data point in the graph indicates mean $\pm \mathrm{SE}$ of five replications.

multipurpose fruit, the post-harvest handling was not largely explored. Thus, this study evaluated the physical, chemical and biochemical activities, and physicochemical properties of macauba fruit and its mesocarp oil quality along 60 days of storage under room conditions. Despite excess mesocarp water activity in the first 40 days, the sharp increase in the decay incidence took place after the 28th day. Mesocarp water activity reduced slowly and reached 0.83 at the 60th day. Specific activity of lipase is highly related to the water activity and ceased after 40 days. On the other hand, acidification increased irrespectively to the reduction of the lipase activity. There was development of oxidative reactions, shown by the increase in the peroxide index and molar absorptivities at $\mathrm{K}_{232}$ and $\mathrm{K}_{270}$. The initial oxidative stability index was very high and it dropped along the storage. Total carotene had two distinct behaviors, along the first 26 days there was synthesis and afterwards there was a degradation phase. Overall, macauba fruits harvested directly from the bunch and stored at room condition maintained a desirable mesocarp oil quality up to 20 days considering the release of free fat acids and development of oxidation.

Acknowledgements. The authors would like to acknowledge The World Academy of Sciences (TWAS) and National Council for Scientific and Technological Development of Brazil (CNPq) for providing the scholarship grant for first author and Petrobras SA for financing the research funds.

\section{References}

Anwar F, Bhanger MI, Kazi TG. 2003. Relationship between rancimat and active oxygen method values at varying temperatures for several oils and fats. JAOCS 80: 151-155.

AOCS (American Oil Chemists' Society). 1983. Official and tentative methods. Champaign, Illinois: AOCS Press.

AOCS. 1997. Official method Cd 12b-92. Champaign, Illinois: American Oil Chemists' Society.

AOCS. 2004. Official methods and recommended practices of the American Oil Chemists' Society. Champaign, Illinois: AOCS Press.
Basyuni M, Amri N, Putri LAP, Syahputra I, Arifiyanto D. 2017. Characteristics of fresh fruit bunch yield and the physicochemical qualities of palm oil during storage in North Sumatra, Indonesia. Indo J Chem 17(2): 182-190.

Bhosle BM, Subramanian R. 2005. New approaches in deacidification of edible oils: A review. J Food Eng 69: 481-494.

Brasil. 2005. Ministério da Saúde. Agência Nacional de Vigilância Sanitária. Resolução Diretoria da Colegiada, RDC/ANVIS/MS $\mathrm{n}^{\circ} 270,22$ de setembro de 2005. Regulamento técnico para óleos vegetais, gorduras vegetais e creme vegetal. Diário Oficial da República Federativa do Brasil, Brasília, DF, 23 set. 2005. Seção 1. Disponível em: http:/www.anvisa.gov.br. Retrieved on December 30, 2014.

Cavalcanti-Oliveira ED, Silva PR, Rosa TS, et al. 2015. Methods to prevent acidification of Macaúba (Acrocomia aculeata) fruit pulp oil: A promising oil for producing biodiesel. Ind Crops Prod 77: 703-707.

Chaiyasit W, Elias RJ, Mcclements DJ, Decker EA. 2007. Role of physical structures in bulk oils on lipid oxidation. Crit Rev Food Sci Nutr 47: 299-317.

Coimbra MC, Jorge N. 2011. Proximate composition of guariroba (Syagrus oleracea), jerivá (Syagrus romanzoffiana) and macaúba (Acrocomia aculeata) palm fruits. Food Res Int 44: 2139-2142.

Del Rio JC, Evaristo AB, Marques G, Martín-Ramos P, Martín-Gil J, Gutiérrez A. 2016. Chemical composition and thermal behavior of the pulp and kernel oils from macauba palm (Acrocomia aculeata) fruit. Ind Crops Prod 84: 294-304. doi: 10.1016/j. indcrop.2016.02.018.

Evaristo AB, Grossi JAS, Carneiro ADO, Pimentel LD, Motoike SY, Kuki KN. 2016a. Actual and putative potentials of macauba palm as feedstock for solid biofuel production from residues. Biomass Bioenergy 85: 18-24.

Evaristo AB, Grossi JAS, Pimentel LD, et al. 2016b. Harvest and post-harvest conditions influencing macauba (Acrocomia aculeata) oil quality attributes. Ind Crops Prod 85: 63-73.

Evaristo AB, Coppel IAF, Guimaraes AC, et al. 2018. Simulation of macauba palm cultivation: an energy-balance and greenhouse gas emissions analysis. Carbon Manag 9: 243-254.

Gerpen JV, Knothe G. 2005. Biodiesel production: Basics of the transesterification reaction. Champaign, Illinois: AOCS Press.

Iaderoza M, Baldini VLS. 1991. A importância da análise enzima em alimentos. In: Iaderoza M, Baldini VLS, eds. Ênzimose a qualidade de vegetais processados. Campinas: ITAL. (Manual Técnico).

Kerrihard AL, Nagy K, Craft BD, Beggio M, Pegg RB. 2015. Oxidative stability of commodity fats and oils: Modeling based on fatty acid composition. J Am Oil Chem Soc 92: 1153-1163.

Lorenzi GMAC, Negrelle RRB. 2006. Acrocomia aculeata (Jacq.) Lodd. EX Mart.: Ecological aspects, uses and potentialities. Available from http://www.entabanbrasil.com.br. Retrieved on 21/04/2014.

Maltini E, Torreggiani D, Vieira E, Bertolo G. 2003. Water activity and the preservation of plant foods. Food Chem 82: 79-86.

Mariano RGB, Silva CM, Couri S, Nogueira RI, Freitas SP. 2011. Partition of free fatty acids in deacidification of macaúba mesocarp oil by liquid-liquid extraction using ethanol/water as solvent. Defect Diffus Forum 312-315: 554-559.

Montoya SG, Motoike SY, Kuki KN, Couto AD. 2016. Fruit development, growth, and stored reserves in macauba palm (Acrocomia aculeata), an alternative bioenergy crop. Planta 244: 927-938. 
Nunes AA, Favaro SP, Galvani F, Miranda CHB. 2015. Good practices of harvest and processing provide high quality Macaúba mesocarp oil. Eur J Lipid Sci Tech. doi: 10.1002/ejlt.201400577.

Pires TP, Sousa ES, Kuki KN, Motoike SY. 2013. Eco physiological traits of the macaw palm: A contribution towards the domestication of a novel oil crops. Ind Crops Prod 44: 200-210.

Poetsch J, Haupenthal D, Lewandowski I, Oberländer D, Hilger T. 2012. Acrocomia aculeata-A sustainable oil crop. Rural 21 Sci World 3: 41-44.

Ramos MIL, Siqueira EMA, Isomura CC, Barbosa AMJ, Arruda SF. 2007. Bocaiuva (Acrocomia aculeata (Jacq.) Lod) improved vitamin A status in rats. J Agric Food Chem 22: 3186-3190.
Rodriguez-Amaya DB, Kimura M. 2004. Harvest plus handbook for carotenoid analysis. Washington, DC and Cali: IFPRI and CIAT, p. 58.

Shahidi F. 2005. Quality assurance of fats and oils. In: Bailey's industrial oil and fat products. New Jersey: John Wiley and Sons, pp. 565-575.

Shahidi F, Wanasundara UN. 2002. Methods for measuring oxidative rancidity in fats and oils. In: Akoh $\mathrm{C}$, Min DB, eds. Food lipids: Chemistry, nutrition, and biotechnology. New York: Marcel Dekker. Available from https://www.taylorfrancis.com/books/e/ 9780203908815/chapters/10.1201\%2F9780203908815-14.

Sigma Plot 10. 2006. Sigma Plot for Windows, Version 10. Systat Software, Inc. Germany.

Cite this article as: Tilahun WW, Grossi JAS, Favaro SP, Sediyama CS, Goulart SDM, Pimentel LD, Motoike SY. 2019. Increase in oil content and changes in quality of macauba mesocarp oil along storage. OCL 26: 20. 